\title{
The Twentieth Century Administrative Explosion and After ${ }^{\dagger}$
}

\author{
Julius Stone*
}

\section{I \\ HISTORICAL AND CONTEMPORARY CONTEXT}

$I^{\prime}$ N THE nineteenth century when the separation of governmental powers was not a constitutional imperative it was nevertheless deemed a moral and political imperative for the preservation of liberty. The precise boundaries between the powers were assumed to be fixed and discoverable, for without this the imperative would be brought to nought. What was not for the judicial power nust be either for the legislative or the executive; and if the subject-matter was not apt for the legislature, then it must perforce fall to the executive. Obviously, as mere mention of the Barons of the Enghish King's Exchequer reminds us, the executive power insofar as it executes rules laid down by the legislator always had "admimistrative" functions in a broad sense. The modern problems of administration are raised by the rapid and unremitting extension of administrative tasks; that is, the tasks of deciding questions and making rules ancillary to legislative activity, under powers delegated by the legislature. ${ }^{1}$

$\dagger$ Fourth annual Walter Perry Johnson Lecture on Law and Public Affairs, University of California, Berkeley, April 11, 1964.

* B.A., B.C.I., D.C.L., Oxford University; LL.M., Leeds University; S.J.D., Harvard University; Challis Professor of Jurisprudence and International Law, University of Sydney (Australia). Fellow of the Center for Advanced Study in the Behavioral Sciences, 1963-64.

1 For an introduction to the general aspects of the growth of administration as a response to legislative difficulties, consequent problems of control, and of the scope and adequacy of administrative law, see CARr, Concerning ENGLis (1941); Friedranin, Law in a Changing Soctety (1959); Friedrich, Constitutionat GoverNMEENT AND DEMOCRACY (1950) (historical perspective on separation of powers doctrine and practice); GeILHORN, GoverNarental RestratNTs (1958) (impact on individual freedon); Kerseit, Partiamentary Superviston of Delegatrd Legislation (1960); Whyatt, The Citzzen and the Adarnistration: The Redress of Grievances (Justice Report, 1961) [hereinafter cited as Wryatr, JUstrce Report]; Feller, Prospectus for the Further Study of Federal Administrative Law, 47 Yare L.J. 647 (1938); Friedrich, Public Policy and the Nature of Administrative Responsibility, 1 Public Policy 3 (1940); Jaffe, An Essay on Delegation of Legislative Power, 47 CoLusc. L. Rev. 359, 561 (1947); Schwartz, The Administrative Process and Congressional Control, 16 Fed. B.J. 519 (1956); materials collected in Simpson \& Stone, 2 LAW AND SocIETY 311-1385 (1949).

For a general account of English administrative law see GrIFritr \& STREet, PrINcipLes op Admondstrative Law (3d ed. 1963), and in the United States see Davis, AdMrmistrative Law Treatise (1958); Gerthorn \& Byse, Administrative Law: Cases and Mate-

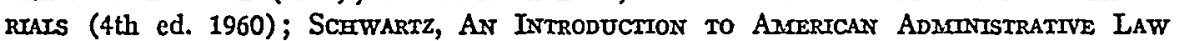
(1958).

On judicial review and control of administrative action see DE SMrTH, JUDrchal RE- 
This extension has been so dramatic since the industrial revolution and has since 1900 followed so steadily the growth of legislative intervention in new areas of economic and social relations, that the traditional separation of powers has seemed threatened at its foundations. Consequently much of the work on public law of the present century has been concerned with the defense of the separation of powers doctrine, or with attempts to find room within that doctrine to accommodate the administrative arm. Either attempts were made to lold administration within a matrix which would allow it to fit into one of the three traditional divisions, or the doctrine of separation of powers was reinterpreted to accommodate what actually goes on in administration. The most important effort of this last kind has been, of course, the translation of the doctrine from one prescribing separation of powers, into one describing distribution of functions according to time and structure and aptitudes available.

This mellowing translation of the separation of powers doctrine into one of convemient division of functions was not to arise until persistent trends compelled it. Well into the present century the approach of lawyers and jurists still presupposed the hteral separation of powers. It became difficult to explain, in such terms, the fact that many tasks given to administration involved the determination of legal rights and duties of citizens involved in controversies, this having been thought to be characteristic of judicial, not of executive power. It also became diff-

view of Adainistrative Action (1959); Galeotti, Tax Judicial Contror of Publtc Authoritues in England and Italy (1954); Hasson, Executive Discretion and Judictal Control: An Aspect of the French Consen d'Etat (1954); Marsose, Judicual Control of Admintstrative Action in India (1956); Parker, Recent Developments in the SUPERVISORY PoWERs of THE CourTs (1959) (Lionel Cohen Lectures, University of Jerusalem); Schwartz, French Admanistrative Law and the Comaron-Law Wordd (1954); Benjamin, Judicial Review of Administrative Adjudication: Some Recent Decisions of the New York Court of Appeals, 48 Colum. L. REv. 1 (1948).

On current controversies about English judicial review see Robson, Administrative Law, in Law and Opinton in Engtand in the 20th Century 193 (Ginsberg ed. 1959); Davis, English Administrative Law-An American View, 1962 Puв. L. 139; Davis, The Future of Judge-Made Public Law in England: A Problem of Practical Jurisprudence, 61 CorUm. L. Rev. 201 (1961); Evershed, The Changing Role of the Judiciary in the Development of Law-The Judicial Process in Twentieth Century England, 61 CoruM. L. Rev. 761 (1961); Jaffe, English Administrative Laz-A Reply to Professor Davis, 1962 Puv. L. 407.

On policy-making by administrative bodies from the legal standpoint see FrEUND, Standards of amarrican Legistation (1917); Friendey, The Federat addanistrative Agencies-The Need for BetTer Definttions of Standards (1962); from the political science and philosophy standpoint, see Schubert, The Public Interest (1960); Wardo, The Admenistrative State (1948).

On current organizational problems see KTNGDOM, IMpProvement of Organisation and Management (1955); Samon, Administrative Behavior (1955); Davis, Institutional Administrative Decisions, 48 CorUM. L. REv. 173 (1948); and (more controversially) BERNstend, Regulating Business by Independent Comomassion (1955). 
cult to explain the wide law-making powers, often approaching blank authority, conferred on executive authorities. For in the teaching of Montesquieu's L'Esprit des Lois (1748), dominant in America since before the Constitution was adopted, to empower one and the same authority both to make and enforce the law was an invitation to tyranny; and to empower that same authority also to determine rights and duties under the rules was tyranny itself. ${ }^{2}$

It was thus not merely the persuasiveness ${ }^{3}$ of A. V. Dicey's thesis in his Law of the Constitution (1885), ${ }^{4}$ but the fact that he expressed a plausible conclusion from assumptions generally shared among lawyers and political thinkers, which made him the oracle of the hostile campaign against the growth of administrative rule-making and adjudication, ${ }^{5}$ and against any compromise with it in the form of an Enghsh droit administratif. ${ }^{\circ}$ The literature has no doubt transcended most of Dicey's posi-

2 For citations as to this and other early classical rationalizations of the separation of powers doctrine see Stone, the Province and Function of LAw 764, n.44 (1946), and, for brief background discussion see $i d$. at 590-93, 775. For a full study of the place of the doctrine in constitutional government, see FrIEDrICH, ConstrTutronad Governarent aND Derrocracx (1950).

3 It is certainly correct to say, as did Justice Frankfurter, that few modern books "have had an infuence comparable to that produced by the brilliant obfuscation of Dicey's The Law of the Constitution." Frankfurter, Foreword to A Discussion of Current Developments in Administrative Law, 47 YALE L.J. 515, 517 (1938). This influence, of course, has been even more pervasive in British Commonwealth countries than in the United States because of the wide use of the book in the former as a standard text for courses in constitutional law.

4 See note 3 supra.

5 Among the best known early expressions were ALIEN, Bureaucracy Trrumperant (1931) and Hewart, NTEw Despotism (1929). See also ALLen, LaW AND ORDers (2d ed. 1956); Morgan, Remedies Against the Crown, in Public AuthoritIEs AND Legax LIABIrITY 1, (Robinson ed. 1925); Robson, Justice AND ADMmistrative Law (1st ed. 1928); Carr, Administrative Law, 51 L.Q. Rev. 58 (1935); Carr, This Freedom, 62 L.Q. Rev. 58 (1946); Committee on Ministers' Powers (Donoughmore Committee), Report, 1932 CMD. 4060; Evatt, The Judiciary and Administrative Law in Australia, 15 CAN. B. Rev. 247 (1937); Simon, Administrative Procedure and the Rule of Law, 1 J. AD. L. 12 (1954). In the United States, see Pound, Aduminstrative LAW (1942) and American Bar Association Reports, after 1933, especially Report of the Special Committee on Administrative Law, 63 A.B.A. Rep. 331 (1938) (when Pound was Committee Chairman); and, for the other view, see Jaffe, Invective and Investigation in Administrative Law, 52 HaRv. L. REv. 1201 (1939); Landis, Crucial Issues in Administrative Law, 53 HaRv. L. Rev. 1077 (1940), especially 1077-80, 1098-1102; Landis, Law and the New Liberties, 4 Mo. I. Rev. 105 (1939).

For an analysis of continuing traces of the hostility on the judicial level see Griffith, Judicial Attitudes to Administrative Powers, $1 \mathrm{~J}$. AD. I. 41 (1954). On the similarity of of the "new opposition" of the last decade to the "old" in the Unted States, see Kintner, The Administrative Process Comes of Age, 16 FED. B.J. 539, 551-55 (1956).

6 That is, a specific body of law apphed by a specific hierarchy of instances established to supervise, control, and check the exercise of powers of administration, of which the French system, headed by the Conseil d'Etat as the supreme administrative tribunal, is the nuost fanious. See Haxsom, Executive Discretion and Judictaz Control: An Aspect 
tions, but the emanations from his views are still important in current debates.

At an earlier stage, however, during the opening decades of this century, lawyers' attitudes were of simple opposition, sullenly adamant when not defiantly clamant. And despite them, the spectacular proliferation of tribunals and powers into the legislative and judicial spheres continued unremittingly. Energy and intelligence, vainly expended seeking to turn back the administrative tide, could not be available for the more practical tasks of building appropriate checks on this new kind of power. Traditions of arbitrariness which should have been challenged and ended have been allowed to linger on; and traditional safeguards against arbitrariness which should have been preserved have even been subverted. ${ }^{8}$

The basic historical context of the rise of the admimistrative arm is precisely the expansion of the range of legal intervention in complex economically organized societies. To accomplish those new tasks for which the capacity of legislative and judicial institutions fell short (for reasons examined in the next section), power was thrust into the ad-

of the French Consell d'Etat (1954); Schwartz, French Administrative LAw and THE Comaron-Law WorLd (1954).

7 Conpare the perhaps overly vigorous manifesto against "talk about the rule of law, about Dicey's misunderstanding, about separation of powers in the abstract, and about ministerial responsibility," in Davis, English Administrative Law-An American View, 1962 PUB. L. 139.

${ }^{8}$ Lawyers' unfamiliarity with administration was no doubt in part responsible. See Robson's unkind words: "Lord Hewart had apparently not heard of any adnunistrative tribunals in Britain since he never referred to then." Robson, Administrative Law, in LAw AND Optanon in Engtand IN THE 20TH Century 193, 196 (Ginsberg ed. 1959). Certainly knowledge came somewhat earkier among American scholars. See, e.g., Freund, ADMINIStrative Powers over Persons and Property (1938); Freund, Standards of American LegISLATION (1917); and the symposium in 47 YALE L.J. 515-674 (1938), especially Landis, Administrative Policies in the Courts, id. at 519; Fuchs, Concepts and Policies in AngloAmerican Administrative Law Theory, id. at 538; and Cooper, Administrative Justice and the Role of Discretion, id. at 577.

As late as 1958 Gellhorn compiled a sample list of arbitrary powers exercised without serious protests in the United States. He noted that censorship powers, powers of withholding governmental information from the public, powers of determining whether persons were "loyal" or "good security risks," and powers in times of crisis to determine whether the personal liberty of political deviants slould be restricted to prevent the possibility of future commission of some offense, have all come to be tolerated with little concession to requirements of even procedural fairness. The issuance of passports to citizons wishing to travel abroad, visas to persons wishing to enter, and many decisions concerning the naturalization and deportation of aliens, which inay often spell bife or death to the alien concerned, continue to be surrounded in the administrator's hands by the jealous inscrutabilities historically associated with the English royal prerogative. Other traditions worth preserving, on the other hand, were being subverted. Administrative power was given to regulate reigstration of printing and mimeograph machines of particular (Communist) organizations; similarly power to determine that organizations. whose activities are otherwise not unlawful are "Communist" was given. See Gexhmorn, Governamental REstraInTS (1958). 
ministrator's hand. In this context then, the powers which fell to administration nuust be seen as residual, arising from the functional and institutional limitations of traditional legislative, judicial and executive organs. This residual nature contributes to the issues raised by the growth of administration. Ubiquitous, confused, multiple, and miscellaneous as these issues undoubtedly are, these qualities but reflect the diversity of reasons for delegation, and the diversity of the subjects of novel legislative concern.

Only less important in its bearing on modern issues is the historical fact that when we speak of that which is "residual" upon the limits of these other functions, we are tacitly bringing into the picture considerations of the over-all range of State interventionism. This in its turn introduces more or less overtly emotional attitudes towards the propriety of this interventionism. ${ }^{9}$ It is well to remember this in approaching the authorities preceding World War II. It reminds us that since the early phases of modern administration its expansion has been tied to social and economic legal interventionism. It was thus natural at that time to identify the newer organs with "progressive" policies, and opposition thereto with "conservatism." On a broader view, however, and from the perspective of the present, this identification may be deceptive. Resort to administration may now moderate rather than inerely follow political antagonisnis.

\section{II}

\section{ADMINISTRATIVE TASKS AS ARISING FROM THE SHORTFALLS}

OF TRADITIONAL LEGISIATIVE AND JUDICIAI ORGANS

The troublesome parts of modern administrative tasks lie above all in the accumulation of delegated powers of legislation and quasi-judicial determination in new areas of legal control. Functionally, the executive was not a particularly apt repository for such new powers; but on the assumption that there were only three powers of government, legislative, judicial and executive, overflow from the first two conld go only to the third. It was thus that the new tasks came to be associated with the traditional executive organs, organs which in their older functions enjoyed the wide inscrutability of the Crown's prerogative. ${ }^{10}$ There was of course

9 This may be one reason for the paradox that the vigor of protest against administrative arbitrariness of the nineteen-thirties, when the central issues concerned state economic interventionism, is not so commonly found in the nineteen-sixties when the central issues are of personal hiberty.

10 As to areas of arbitrary discretion associated with the prerogative power, $c f$., WhyATT, JUSTICE Report 16. For general accounts of modern Umited Kingdom agencies see Administratrve Trmbunats at Work (Pollard ed. 1950); Wintson, Admmistration IN ACTION (1960). 
no necessary reason why the new functions should be cloaked with either the supremacy of the delegating legislature, or the traditional prerogative immunity of the executive. Yet confusion was bound to arise as the halo of traditional executive immunity drifted around most of the new functions. In this confusion the idea of a system of administrative law and attendant courts was easily misinterpreted (with appropriate hostility) by Dicey and his followers as an attempt to extend and regularize the exceptional freedom of executive authority from judicial controls.

It now seems clear that nodern administrative power, despite these dubious historical associations, nust be viewed as a distinct and largely new constellation of functions. To accommodate this reality, thinkers have successively sought to redefine the executive function, ${ }^{11}$ or to separate the "administrative" from the executive function by attaching it to Congress, ${ }^{12}$ or have come to the view that administration must be seen finally as neither of these. The version of this last view which comes nearest to the present writer's position is that the administrative function has developed within the space left, under modern exigencies, by the three traditionally separated powers, and that thougl in a sense administration subverts this tripartite system, it does so only by becoming a distinct kind of focus of power necessary to maintain that system in new circumstances. Even if this reinterpretation were not acceptable in itself, we would still have to say that unless we see and treat administration as a function distinct from the traditional executive, the task of building rational safeguards against arbitrary use of its power will remain mostly out of reach. Certainly, Anglo-American practice has moved in the last two generations fitfully but steadily towards admission of these functional realities.

\section{A. Legislative Shortfall}

In part, the functional differentiation of administrative process must be in terms of the institutional and practical limits of traditional legislative and judicial action. We may first observe some of the respects in which the responses of legislative organs to the exigencies of new tasks were so inadequate as to require the virtual establishment of a fourth

11 This was done by the United States Committee on Administrative Management when it advocated the restoration of the President to "his proper place as Chicf Executive." United States Comar. on AdmInistrattve Managemant Report 31 (1937).

12 See Brookifgs Institution Report, Investigation of Executive Agencies, S. REP. No. 127, 75th Cong., 1st Sess. (1937) discussed in Wardo, The Admonistrative State 118-19 (1948). Cf. Frank, If Men Were Angeis (1942); Landis, The Administrative Process (1938); Waddo, The Admrnstrattve State 120-121 (1948); and on the interplay of executive (political) and administrative powers, see Friedrich, Public Policy and the Nature of Administrative Responsibility, in 1 PublIc PoxICx 3 (Fricdrich \& Mason ed. 1940); Gulick, Politics, Administration and the New Deal, 169 Annals 55-56 (1933). 
branch of government with all its attendant perplexities. In giving some precision to these himitations, we shall be sketching the special functional aptitudes of administrative organs, for these are complementary to the shortfalls of other institutions. ${ }^{13}$

The shortfalls in legislative aptitudes are broadly of three kinds: ${ }^{14}$ (1) limits on time available; (2) limits of specialized knowledge required in new areas of legal control; and (3) limits on organizational aptness for exercising continuous supervision over legal development in areas where detailed rules or even policies must grow by experience.

No doubt, new organizational forms and flexibilities might increase the effective use of legislative time (as well as of judicial); and no doubt, too, the traditions and prestige of these institutions make adaptation to changing functions slow and inadequate. Yet even apart from organizational sluggishness and inertia, the very volume of delegation by legislatures, and of the ensuing mountains of regulations and determinations, testifles that we have lere no mere problem of reorganization.

Moreover, legislative business now embraces nuch in which decision presupposes expertise not possessed by legislator or judge. Matters of expertise embrace here not merely esoteric matters, like those of physical science and technology, but also matters of apparently general knowledge which may have to be dealt with under aspects which are beyond general knowledge. They may be moved from the general area into that of expertise by any of a number of factors. One is the adoption into law of new kinds of social pohcies addressed to little-understood aspects of familiar institutions, as when the law is moved to support marriages by techniques of conciliation, or to promote actively "the welfare" of the child. Another is the emergence from social activity of new problems in which experience is virtually lacking, as problems of congestion and injuries on the roads in the age of the automobile are tractable, if at all, only to expertise. A legislature may also have to invoke expertise in matters of apparently general competence because of the discovery of new knowledge, though this more usually acconipanies one or both of the two preceding situations. Air pollution resulting from industrialization and urbamization long preceded any expertise in controlling it. Appearance of the new expertise spelled delegation of powers to fix tolerated standards of pollution, and to make regulations for policing these stand-

13 Among many judicial recognitions of the realities operating here, see statement of Kitto, J., in R. v. Davison, 90 Commw. L.R. 353, 381-83 (Austl. 1954).

14 See the valuable discussions, in terms of "organizational" or "institutional" decision, of the need to draw maximun advantage on an adequately informed basis from the flexibilities of administrative forms in SmMon, AdMrnistratrve Benavior (1948); Davis, Englisit Administrative Law-An American View, 1962 Pणв. L. 139; Davis, Institutional Administrative Decisions, 48 CoLUn. L. Rev. 173 (1948). 
ards, much as the growth of psychiatric and criminological knowledge is still transforming problems of sentencing and parole.

Other limits on legislative as well as judicial abilities which feed the new admimstrative functions arise from the need for continuing supervision, and adaptation to accumulating experience, of many of the new essays in legal intervention. Here, above all, it is the traditional patterns of legislative and judicial institutions which set the limits of what is possible. ${ }^{15}$. For example, a most fertile source of the conjuncture of imperative need for control with present inability to design the control is the dynamic movement in science and technology. L. L. Jaffe las drawn attention to an analogous situation, also of deep interest in the present context. ${ }^{16}$ Earlier Anglo-American thinking, when not simply condemning the admimistrative delegate as a usurper, sought to rationalize his role in the democratic process as one of filling in detailed rules for the pursuit of legislatively set or otherwise non-controversial goals, thus saving the principle of democratic consent. In the reality that lias emerged, however, it is clear that delegated powers often extend well beyond this to the very determination of goals, sometimes even of final goals. And the truth is that legislative or community consensus sometimes extends only to the decision that the particular area slould somehow be legally controlled. The allocation of administrative power then presents itself as the only means of preventing that limited community consensus from being frustrated by continuing disagreement as to the appropriate means. ${ }^{17}$

When we recognize this role of admimistration in the area of legislative shortfall, we are faced with grave questions as to the relation between administrative policy-making and legislative and executive responsibility. Granted that legislative delegation of policy-making may often be inevitable, it may also often be a dereliction of the legislature's responsibility. ${ }^{18}$ In either case, lowever, it raises a lost of questions besides those of surveillance of admimistrative exercise of delegated power.

In approaching these other questions, much discussed in connection with evaluating the work of independent administrative agencies such as the Federal Trade Commission, Interstate Commerce Commission, and Civil Aviation Board, we should recall certain earlier observations. Mod-

${ }^{15}$ This was much stressed by Jaffe in An Essay on Delegation of Legislative Power, 47 Cosuns. L. REv. 359, 363 (1947).

$16 \mathrm{Jaffe}$ supra note 15, at 367-69. Cf. Jaffe, Book Review, 76 HaRv. L. Rev. 858, 86263 (1963). He also argued, in defense of independent administrative agencies, that thcir failure to develop coherent and dynamic policies pursuant to the mandates was not necessarily a default. See Jaffe, Book Review, 65 YaLE L.J. 1068, 1075-76 (1956).

17 See corresponding censure of agencies for failure to formulate coherent policies in Bernstent, Regulating Business by Independent Comanossion (1955). On the difficulties of divining consensus, see Hyman, The American Presment 52-53 (1954).

${ }_{18} \mathrm{Cf}$. Schwartz, The Administrative Process and Congressional Control, 16 FED. B.J. 519 (1956). 
ern administration falls heir inter alia to functions residual on the limited capacities of legislative and judicial organs. Its identification with executive power is not really self-evident, and it is in this sense a distinct kind of power. ${ }^{19}$ Yet in escaping the strait jacket of the tripartite separation of powers, we should avoid being thrust into a quadripartite one, by dogmas requiring that administration always be divorced at all costs from the executive power.

The independent agencies, as experiments in such divorce, have been subjected to censures. One is that such divorce deprives the agency both of leadership and popular support for policy initiatives, which association with the executive power and its prestige might otherwise afford. ${ }^{20}$ Another is that the unintegrated activities of such agencies bring fragmentation and confusion to national policies into which their work slould fit. ${ }^{21}$ All this, furthermore, nray impair the agency's own performance, leaving it vacillating between the shifting viewpoints of its members, and exposing these nrembers to the pressures of special interests. This in turn tends to encourage the members to maintain the status quo in self-protection rather than to venture on self-exposing initiatives that their tasks may really require. No conceptualization in separation of power terms is necessary to see either the advantages for agency initiative, planning and coordination, resulting from relations with the Executive, or the disadvantages from these relations for adjudication in which the Executive may have its special interests. ${ }^{22}$

The weight of such criticisms must vary widely for different independent agencies. ${ }^{23}$ Moreover, the assumption that association with the executive power would unify national policy is subject to the comment that the mere unity of the office of President does not guarantee executive ability to coordinate even its own policies. Surgery therefore in cutting administrative policy-making away from adjudication and grafting it onto executive power would still leave policy coordination a matter of more or less. This last point assumes that administrative policy-making and adjudication are in fact substantially severable, but of course, "adjudication" is itself not only concerned with the implementation of policy, but is also often formative of policy. In short, divorce of these two

18 See the stimulating critiques of BERNSTEn, op. cit. supra note 17, by Schwartz, Book Review, 69 HARV. L. Rev. 960 (1956) and Jaffe, Book Review, 65 YalE L.J. 1068 (1956). See also the important defense of the I.C.C. by its chairman: Arpaia, The Independent Agency, 69 HaRV. L. REV. 483 (1956).

20 Bernstenn, op. cit. supra note 17; Schwartz, supra note 19. Coinpare Jaffe, supra note 19.

21 Cf. Schwartz, supra note 19, at 962.

22 Cf. id. at 962-64.

23 Jaffe points out that some exaggeration of censure arises from disappointment of equally exaggerated hopes of champions of the administrative process. Jaffe, supra note 19, at 1069 . It should not conceal an impressive level of performance by many agencies. 
aspects of administrative activity for the sake of marrying policy-making to the Executive, may in many instances do more harm than good. ${ }^{24}$

Nor would association with the Executive necessarily ensure better performance of the agency's duty (when it exists) to clarify policy. When the legislator has required that an agency shall regulate, but leaves it to work out policy for that purpose, the agency may often be as balked as the legislator by lack of any stable community consensus. It may nevertheless be the agency's duty to crystallize some more precise policy than the symbolic "public interest," and thereby force Congress either to acquiesce or to provide an alternative. Yet it is immaterial for this purpose whether the agency is independent or executive-dependent.

Some generalities of course do offer prima facie guidance. One is that an independent agency is functionally apt for a compact set of tasks which are predominantly quasi-judicial. A second is that where there are substantial tasks of regulative policy-making which frequently toucl areas of executive concern, these tasks should not generally be given to independent agencies. $A$ third is that any area of quasi-judicial activity where continuing lines of decisions cannot be colierently accounted for calls for close review. This may show that for some reason the organ concerned is functionally inapt. Or it may show that the relations under regulation are in a transitional phase which warrants patience in awaiting the eniergence of clearer policies. Or it may be that the incoherence arises from the need to meet quickly varied emergencies. Putting out a fire involves numerous decisions; but beyond the broad policy of saving life and property from fires it would be difficult to lay out the principles on which these decisions are always to be made. Or finally it may have to be concluded that the State and its law slould not have entered the particular field at all, and that they slould withdraw if possible. All such generalities, lowever, are only prima facie, for in societies so changeful as at present, transitional phases may be long protracted before coherent detailed policies can energe which are viable from case to case and from year to year.

\section{B. Judicial Shortfall}

The functional differentiation of administrative decision must also be partly seen in ternis of the limits of judicial action. The problems of time and expertise available, and those of continuing supervision and guidance affect judicial as well as legislative capacities. Attempts have indeed been made to show that there are precise analytical boundaries of the "judicial" function, so that controversies lying outside these must be left to

24 Cf. Jaffe, supra note 19, at 1071-75. And for examples of the agencies' tendency to alternate between strict and loose views in this situation (especially the anti-trust division of the Justice Department and the Federal Trade Commission), see ibid. 
"non-judicial" organs. Sometimes, even today, the test offered for "judicial" nature is whether a controversy exists in which the tribunal must determine the rights and duties of opposed individuals. This has proved in the long run quite unhelpful, for it is clear that these same elements are present in a considerable number of indubitably "administrative" determinations; and this is probably why it is now common to call them "quasi-judicial." Sophisticated analytical effort has more recently pressed a more complex analysis of the judicial function as a "form of social order."24a This goes beyond earlier notions nuainly in the claim that the judicial process is not apt for controversies which are "polycentric," that is, which involve numerous foci of dispute, the decisions on sonve of which may depend on how others are concurrently determined.

This suggestion has general value, subject to certain reservations as to the rigidity with which it is insisted upon for practical purposes. When offered $^{25}$ to mark off administrative from judicial determinations, however, it faces particular difficulties. For even if it were the case that all decisions left to administrators were "polycentric," the contrast would still often prove dubious on the judicial side of the division.

Because judicial proceedings usually are adversary and involve only the claims of two directly opposed parties, it does not mean that they are never or even only rarely "polycentric." Such a generalization concerning judicial activity is sinply not correct. For, certainly as to the appellate level, it is now conmonplace that a court niay and should take into account all interests affected by the rule which it is asked to apply or develop, or are otherwise involved in its decision. This nuay frequently be seen in the exercise of discretion in the grant of divorce, or in fixing the himits of so-called "strict liability" in tort, or in fixing the insurer's rights of subrogation in the context of modern insurance practice, or in issues involved in "public policy" doctrines, and many other matters. Polycentrism of issues, even if we forget such obvious areas as anti-trust and due process decision-making, is not sufficiently alien to judicial activity to distinguish it with analytical sharpness fron many administrative determinations.

\section{III}

\section{IIMITS ON LEGISLATIVE AND JUDICIAI CONTROL OF ADMINISTRATION}

The problems of control by the legislature and judiciary of administrative decision have been traditionally the main focus of lawyer-concern

24a See Stone, Soctar Dimenstons of Law aNd Jusxice ch. 14, §§ 4-5 (forthcoming, 1965). See generally G. Marshall, Justiciability, in Oxrord EsSAYs IN JURISRRUdence (Guest ed. 1963); Summers, Justiciability, 26 Modern Law Rev. 530 (1963).

25 This is done by Jaffe in English Administrative Law-A Reply to Professor Davis, 1962 Pus. L. $407,413$. 
with administration. These problems remain important and largely unsolved. A substantial part of administration does no doubt conform to the preconception that administrators merely implement democratically determined policies. This is a basic fact for attempts at legislative control. Yet, as we have just seen, this is not the whole picture. Over substantial basic areas mcluding the National Labor Relations Act, ${ }^{20}$ and anti-trust law, ${ }^{2 \tau}$ judges and administrators alike must simply do what they can to determine the policies involved, with little if any legislative guidance or conmrunity consensus. Where, as in the United States, the allocation of the several governmental powers to particular organs is constitutionally laid down, the fact that legislative power is vested in the Congress means that Congress must give some guidance to the administrative decision-maker. He cannot in constitutional theory receive a blank check..$^{28}$ Yet in retrospect it cannot be said that the outcome of half a century of American practice is fundamentally much different from that in Britain, though there a blank check is legally possible. The vague indeterminancy of such standards as "the national interest" or "the public interest" is hittle sliort of unfettered discretion, as are many intermediate standards to which appeal is often made.

The question of how to ensure that day to day administrative activity respects the legislative consensus on policy, is thus omnipresent, urgent and (regrettably) still largely unsolved. The tabling of admimistrative regulations in the legislature before or after entry into force has no more answered it than it has established control over administrative arbitrariness. ${ }^{29}$ Such formal steps have certain values ${ }^{30}$ which aid surveillance, and in particularly dramatic cases nray even catalyze a burst of anxiety and effort at reform. ${ }^{31} \mathrm{But}$ in the long run the same handicaps in the legislative process, which originally dictated the delegation, also bar the possibility of effective regular scrutiny. Prompt publication and ready

26 Cf. Packard Motor Car Co. v. N.L.R.B., 330 U.S. 485 (1947).

27 Cf. Ilbert, The Mechantcs of Law-Making 19-23 (1914); Jaffe, English Administrative Law-A Reply to Professor Davis, 1962 PUB. L. 407, 413-16.

28 See the discussion of Ann Arbor R.R. v. United States, 281 U.S. 658 (1930), in Jaffe, An Essay on Delegation of Legislative Power, 47 Colum. L. REv. 359, 366-69 (1947).

29 See Carr, Concerning English Adminstrative Law (1941); Jaffe, An Essay on Delegation of Legislative Power, 47 CoLum. L. REv. 359, 372-74 (1947).

30 For a re-examination with a view to expanded use in the United States, see Note, 65 HaRv. L. Rev. 637 (1952). See also Griffith, Delegated Legislation-Some Recent Developments, 12 MODERN L. Rev. 297 (1949). On the various parliamentary techniques of surveillance in Commonwealth countries, see Kerserl, Pardiamentary Supervision of DedeGated Legisiation (1960).

31 On the official reports and literature leading up to and assessing the improvement in publieation and access in the United Kingdom and the United States, see the short account of Carr, Administrative Adjudication in America, 58 L.Q. REv. 487 (1942), and Jaffe, Administrative Procedure Re-examined, 56 HARv. L. Rzv. 704 (1943). 
access to regulations and decisions is an important prerequisite to control of any kind. Yet it is little more than this, and it scarcely touches the question of paramount control of administrative policy-making. ${ }^{32}$ Nor have the difficulties of legislative surveillance been overcome by occasional essays in supervision by legislative standing committees which clearly have not succeeded in establishing legislative control of the day to day administrative implementation of policy directives. Such day to day control is one thing; it is quite another to subject administrative implementation to occasional legislative sorties which may or may not be inspired by the public interest. ${ }^{33}$

The more effective external checks on administrative policy-implementing and policy-making activity are likely to be of a rather different and less direct nature. Judicial review is only a marginal check on policymaking; but it is supplemented by developing grievance procedures such as those associated with the Ombudsman or Parliamentary Commissioner offices which we cannot here pause to examine. As the issues become clearer, more careful attention is being paid even in Anglo-American countries to the structure, membership and hierarchical position and procedures of the particular delegate organ, to ensure broadly a certain independence and objectivity as between the public interests and private interests which it is the organ's task to adjust. There are also being established, despite the haunting ghosts of Dicey's doctrines, principles of administrative recourse for review of day to day administrative determinations. In the background, of course, there hovers always the possibility of a press and parliamentary furor over particular instances of administrative caprice or bêtise. Such causes célèbres have sometimes served in England as powerful levers, clearing the rubble of history which lies in the way of an orderly system of controls of administrative action. ${ }^{34}$

Nothing but "theocratic myth," it has recently been charged, with lawyers as its "priesthood," supports the title of the judiciary in a democratic society as the final arbiter of whether the action of eacli branch is within the constituent grant; ${ }^{35}$ and arguments that judicial review of the propriety of admimstrative decision best serve "the public interest"

32 For an expression of fear, contrarily, of undue concentration of power in Congress in this context, see Ginnane, The Control of Federal Administration by Congressional Resolutions and Committees, 66 HaRv. L. Rev. 569 (1953).

${ }^{33}$ See Newman \& Keaton, Congress and the Faithful Execution of Laws-Should Legislators Supervise Administrators?, 41 CALIF. L. Rev. 565 (1953).

34 See note 39 infra.

35 This continues, of course, in the contemporaneous setting, the hoary controversies surrounding the great case of Marbury v. Madison, 5 U.S. (1 Cranch) 137 (1803). 
are said to be question-begging. ${ }^{36}$ Writers who thus reject the judicial title to be vox populi are also likely to reject the Executive's, on the ground, for example, that the President himself is partisan. They may be found also questioning the title of Congress, ${ }^{37}$ thus clearing the scene by this interesting game of musical chairs for the maturation of administrative power.

What is now argued about in these terms is not, of course, whether there slrould be judicial review at all, but rather what should be its purposes, and consequent ambit? On its face three purposes of review are liere nlost in point: first, to check abuse at détournement ${ }^{38}$ of such power; second (overlapping in part with this), to ensure to citizens an impartial determination of their disputes with officials; third, to protect them from unauthorized encroachment on their rights and interests. ${ }^{39}$ Such purposes, moreover, must be souglit in ways which still permit the agency to bring to its assigned tasks a modicum of efficiency. What ambit of judicial review is necessary and possible to these ends is the subject of deep and often bitter differences. In England the judges from the start tended to limit review to issues "going to the jurisdiction" and to the procedural "principles of natural justice" where quasi-judicial power was in question. Despite much case law and controversy these concepts are still affected by considerable indeterminancy, ${ }^{40}$ as well as by historical technicalities arising from the prerogative writs. ${ }^{41}$

The nodern English judicial attitude is naturally deferential to whatever disposition of power Parhament has chosen to make, ${ }^{42}$ though it

36 Schubert, The Public Interest 78 (1960).

37 See, e.g., id. at 47-64, especially $52-53,57$.

38 That is, where the administrative exercise of power is intra vires as to its quantum, but it is exercised for a purpose ahen to that for which the power was granted, even if the diversion be not corrupt. Protection against such diversion is given by the French droit administratif, but not as such in many common law countries. See note 6 supra.

$39 \mathrm{Cf}$. WhyatT, Justice Report 27. The problem shades out, of course, into the diffcult ground of extreme harrassment by gratuitous bungling and persecution. See Griffith, The Crichel Down Affair, 18 MODERN L. REv. 557 (1955).

40 For a recent account see DE Simtre, Judiciar REVIEW of AdMonistrative Action ch. iii (1959), especially 69-70. For interminacies in the audi alteram partem principle of natural justice, produced by holding in the range of functions deemed to be "judicial" for the purpose of this principle, cf. Ex parte Fry, [1954] 1 WEEkry L.R. 730 (C.A.). The holding is the more remarkable as claiming to be particularly apt for public officers exercising disciplinary power.

41 It seems strange at this stage however to think that peremptory abolition of these historical residues could itself bring any major reform. But see Davis, Future of JudgeMade Public Laze in England: A Problem of Practical Jurisprudence, 61 Colum. L. Rev. 201, 204 (1961). For constructive approaches (e.g. in terms of use of the declaratory judgment), see Barnard v. National Dock Labour Bd., [1953] 2 Q.B. 18, $41-44$ (C.A.) (per Denning L.J.); Denneng, Freedom Under Law (1949); Schwartz, Forms of Review Action in English Administrative Law, 56 ColuM. L. Rev. 203 (1956).

42 This is true at times even when parkamentary choice is dubious as in Liversidge $v$. 
may be far from clear whether a particular judicial holding that a statute has dispensed with a jurisdictional requirement is really compelled by the statute, or is judicially self-imposed. ${ }^{43}$ If, as one might expect, judges tend to interpret statutory delegations so as not to exclude judicial review, there is also a mamifest judicial reluctance to review the merits of the exercise of discretion involving pohcy elements. ${ }^{44}$ This reluctance would arise in part from proper diffidence as to whether on such matters judges can do better than administrators, even if (as is not the case) policy were generally regarded as judicial business. Yet all this is small comfort to the litigant whose more deep-felt grievances often concern, not jurisdiction or procedure, but the denial of his substantive rights, for instance the value of land compulsorily acquired. In contemporary Britain all political viewpoints seem united in a consensus of uneasiness about the inadequacy of judicial and other controls of administrative discretion. ${ }^{45}$ Judicial attitudes themselves are less changeful. Indeed, a learned Lord Justice has roundly questioned whether "the common law" lias "the strength to provide any satisfactory solution" to the problem of controlhing the executive, including presumably admimistrative power. And this juxtaposition is perhaps an appropriate note on which to approach various proposals for radical reconstruction of the principles of judicial review of admimistrative action. ${ }^{46}$

There are three main lines of such proposals. The first challenges lead-on the assumption that the growth of admimistration presents to the judiciary only the task of keeping the power of the delegate intra vires

Anderson [1942] A.C. 206 (1941). See, e.g., Stone, LegaI System and LawYers' ReasoNings (1964); Parker, Recent Deveroparents in the Supervisory Powers of the Courts 51-56 (1959) (Lionel Cohen Lectures, University of Jerusalem). On English judicial attitudes see Griffith, Judicial Attitudes to Administrative Powers, 1 J. Ad. L. 41 (1954).

43 See Jackson, Judicial Review of Legislative Policy, 18 MODERN L. Rev. 571 (1955).

44 Compare Pyx Granite Co. Ltd. v. Ministry of Housing and Local Gov't, [1959] 3 All E.R. 1 (H.L.) with Fawcett Properties Ltd. v. Buckingham County Council, [1959] 2 All E.R. 321 (C.A.). See de Smith, Note, 22 Modern L. Rev. 664 (1959); Penmington, Judicial Review of Administrative Action on the Merits, 1 J. AD. L. 111 (1954).

45 See notably the Fabian Society tracts, BarRIE, Justice aNd THE AdMTNistration (1957); Crossaran, Soctatism and the New Despotism (1956); and the Inns of Court Conservative and Unionist Society's pamphlet, RULE of LAW (1955). These and related evidences are discussed in Robson, Administrative Law, in LAw aND OpINTON IN ENGLAND IN THE 20TH CeNTURY 193, 198 (Ginsberg ed. 1959). Crossman is particularly concerned to show the consistency with socialism of a critical attitude towards administrative power.

46 Devlin, The Common Law, Public Policy and the Executive, 9 Current Legax Problems 14 (1956). Cf. Blom-Cooper, An Ombudsman in Brilain?, 1960 Pub. L. 145. Davis, Future of Judge-Made Public Law in England: A Problem of Practical Jurisprudence, 61 CoLuar. L. REv. 201, 219-20 (1961), differs on this point only in degree of pessimism. Frankfurter, Foreword to $A$ Discussion of Current Developmenls in Administrative Law, 47 YaLE L.J. 515, 517 (1938). For early pioneering efforts see FreUNd, STANdards of AMerican Legislation (1917) and Goodnow, Comparative Admitstrative Law (1893). 
the grant. This is linked generally with rejection of what Justice Frankfurter has characterized as "the misconceptions and myopia of A. V. Dicey," ${ }^{\prime 47}$ and with proposals for a system of admimistrative courts to apply and develop the body of administrative law, the existence of which the orthodox view is said to ignore. ${ }^{48} \mathrm{~A}$ second line of proposals fixes directly on planning and policy determinations as the distinguishing function of administration. It urges therefore that while judicial review should extend to operational decisions under such determinations, it should not extend to the planning and policy determinations themselves. ${ }^{40}$ A third approach seenis to cut across this. It is that hitation of review to jurisdictional-type matters triviahses control, since arbitrariness "on the merits" and abuse of power are no less serious problems. Under this view, courts should attend to "the policy reasons for and against each possible solution, ${ }^{, 50}$ as well as to its jurisdictional propriety and procedural fairness.

This third kind of demand for "policy review" overlaps with demands under the first position above for a system of droit administratif analogous to that administered by the Frencl Conseil d'Etat. ${ }^{51}$ In assessing them both we need to recognize that Enghish practice goes in some respects beyond the appearances. For instance English judges, though using concepts ostensibly excluding "the merits" of the case, do on occasion produce results indistinguishable from handling "the merits." Thus while they do not recognize the doctrine of detournement de pouvoir, they are prepared, with very similar effects, to check administrative discretion on the ground that it was exercised for motives alien

47 See authorities cited note 2 supra. For recent rather optimistic assessments of the English judicial performance, see ParKer, op. cit. supra note 42; Evershed, The Judicial Process in Twentieth Century England, 61 CoLurr. L. REv. 762 (1961). See especially the rejection in the former of the need for a droit administratif, and the defense of the "jurisdictional question" basis of judicial review in PARKER, op. cit. supra at 785-89.

48 Compare the scope of DE Sartin, Judictar Review of Admtnistrative Action

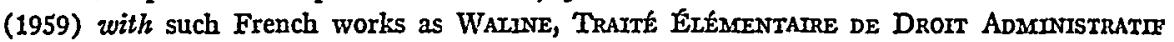
(6th ed. 1951) embracing (besides the traditional Anglo-American topics) such matters as the forms of administrative agencies; the internal himits on and the general manner of exercising discretion; the acquisition and management of property by the administration; public works; and the general obligations of administration. On the French droit administratif in relation to the Anglo-American position, see ScHwartz, AN InTroducrion to AMertcan AdMTNISTRATtVe Law 2-5 (1958).

49 See Frifdmans, Law in a Changing Societr 347-70 (1959). On the planningoperational distinction, see Dalehite v. United States, 346 U.S. 15 (1953); Davis, Tort Liability of Governmental Units, 40 MINN. L. Rev. 751 (1956).

50 See Davis, Future of Judge-Made Public Law in England: A Problem of Practical Jurisprudence, 61 CoLdM. L. Rev. 201, 201-10, 219-20 (1961), discussing DE SMITI, JU. Diciat, Review of AdMTnistrative Action (1959).

51 See note 6 supra. 
to the purposes of the grant..$^{52}$ Moreover, within the administrative system itself there are already reviewing organs of considerable independence, impartiality and regularity of process. ${ }^{53}$

This "policy-review" position is, in other respects, at once more radical and more mild than that demanding a comprehensive system of droit administratif. It is milder in that it does not call for a whole hierarcliy of reviewing instances within the administrative arm. It is more radical in insisting that judges must attend to policy in every case, if only for the preliminary purpose of deciding what kind (if any) of judicial review is called for in that kind of case. And where review should extend to policy it demands that judges accept the responsibility of substituting, if necessary, their own judgment on the merits for that of the administrator. Out of judicial determinations of this sort, it is said, general principles will in due course arise. The prospects for so drastic a reversal of judicial attitudes to overt policy-making seem even dimmer in judicial review of administrative action than in appellate adjudication itself. ${ }^{54}$ The prospects for some kind of administrative hierarchy of recourses are perhaps somewhat brighter, and they are aided by able comparative accounts of the French system (and especially of the efficiency and prestige of the Conseil d'Etat ${ }^{55}$ ) which cast Dicey's preconceptions increasingly into limbo.

52 Marshall v. Blackpool Corp., [1933] 2 K.B. 339 (C.A.); R. v. Minister of Health ex parte Davis, [1929] 1 K.B. 619 (C.A.); R. v. The Vestry of St. Pancras, 24 Q.B.D. 371, 375-76 (C.A. 1890) (per Lord Esher, M.R.); and other authorities discussed in Treeves, Administrative Action and Judicial Control, 10 MODERN L. REv. 276 (1947). Compare the refusal of the Australian High Court to attribute to the legislature the capricious intention to "handcuff" judicial review to the particular mode of valuing 'shares for stamp duty "which the administrator had in that case chosen." Commissioner of Stamp Duties (N.S.W.) v. Pearse, 84 Cosorw. L.R. 490, 519 (Austl. 1951). Compare, on appeal, 89 Cosarw. L.R. 51, 61-62 (Austl. 1953) (P.C.). We do not follow Mr. Treeves' point that the requirement of "reasonableness" is not a legal limitation on the administrative discretion. See Treeves, supra at 288. On continuing problems, see R. v. Minister of Housing and Local Government ex parte Finchley Borough Council, [1955] 1 Weekly L.R. 29 (C.A.) (especially on classification of administrative functions in relation to judicial supervision).

53 See the valuable brief accounts in WHYATT, JUSTICE REPORT 12-26, especially at 13, 19, 23-24; Safford, The Creation of Case Law Under the National Insurance and National Insurance (Industrial Injuries) Acts, 17 MODERN L. REv. 197 (1954). On the danger of over-legalism here, see Sheridan, Late National Insurance Claims: Cause for Delay, 19 MODERN L. REV. 341, 360-64 (1956).

54 See the unusually (if not unduly) sharp reaction to some of Professor Davis's positions in Evershed, The Judicial Process in Twentieth Century England, 61 ColoM. L. REv. 762 (1961).

65 See especially Gadeotri, The Judictal Control of Public Adthoruties in England and in Italy (1954); Hamson, Executive Discretion and Judictal Contros (1954); Schwartz, Frence Admintstrative Law and the Common Law Worid (1954). See also Stone, Soctal Dnamsions of LaW and JUstice ch. 6, \$§ 21-22 (forthcoming, 1965). 
Yet it would be rash to expect an early systematic changeover in Anglo-American countries. Adoption of a "Conseil d'Etat system" would involve far more than mere political decisions. The work of the Conseil is the crown of the remarkable institutions of higher education for the public services in a country hike France; its prestige also reflects in part the different nature of a system of judges especially trained for the judicial career. So, quite apart from problems of training, recruitment for a cadre of administrative judges would not easily attract the best minds in Anglo-American countries. Nor should we underrate the continuing resistance of lawyers, despite the fading of Dicey's positions. The simple fact of unfamiliarity with the ways of a new hierarchy is a formidable obstacle. Even French lawyers of the provincial bar resented the establishment of regional organs of the Conseil in the important recent reforms. ${ }^{60}$

Admitting all this, we should not overlook the substantial progress already made in producing regularity and uniformity in administrative procedure recourses. The controversies, inquiries and reports punctuating the last half century of English development have produced many salutory changes. A number of the proposals of the Franks Committee are of deep relevance to the question of judicial review. ${ }^{57}$ The most important proposal which secured acceptance was the establishment of a standing Council on Tribunals, with appellate functions in respect of determinations for which other appellate recourse is not provided. ${ }^{68}$ Another which gained acceptance was that appeals from tribunals should generally he on the facts and the merits as well as the law, appeal on the law being normally to the courts, with determinations of fact or merit being accompamed by reasons. No less important was the extension of legal aid to claimants before tribunals. ${ }^{50}$ All this does register move-

${ }^{56}$ See Brown, The Reform of the French Administrative Courts, 22 MOderN L. Rev. 357, 377-79 (1949).

57 Report of the COMMTtTeE on AdManistrative Tribunats and Enquires [Chairman, Sir Oliver Franks] (1957) (Cmnd. 218). See the Tribunals and Enquiries Act, 1958. Compare, on a number of aspects, the Administrative Procedure Act, 60 Stat. 237 (1946), 5 U.S.C. $\$ \S 1001-11$ (1958), and the work of the Office of Administrative Procedure in the United States Department of Justice. See Carr, The Non-Judicial Judge, 65 L.Q. REv. 188, 192 (1949); Davis, Ombudsmen in America, 1962 Pив. L. 34.

58 On the first two years work of the Council, see Wade, The Council on Tribunals, 1960 PUB. L. 351.

59 Cf. Comantssion on Organtzation of the Executive Branch of the Governarent [Hoover Comantssion], Legat Services and Procedure: A Report to the Congress (1955) and Conomassion on Organtzation of the Executive Branch of Governarent [Hoover Comantssion], Task Force Report on Legal Services anp Procedures (1955). Other Franks Committee proposals (notably concerning the appointment of tribunals and the publication of inspectors' reports) were not accepted. See $578 \mathrm{H}$. C. DEB. (5th ser.) 1142 (1957); 575 H.C. Deb. (5th ser.) 400 (1957). 
ment (though scrappily and at a distance ${ }^{60}$ ) towards a kind of $d r o i t$ administratif and Conseil d'Etat system. ${ }^{61}$

\section{IV}

\section{DISCRETION, JUSTICE AND STANDARDS IN ADMINISTRATION}

As with judicial discretion, the presence of administrative discretion carries responsibility, as well as the dangers of abuse and derehiction. Here, too, the heart of discretion is the duty to choose, and the duty to choose imphes not only advertence to relevant facts, but a value-decision, a decision of justice, which overleaps any mere dictate from the facts. Administrators are left in such areas of discretion with even starker responsibility than appellate judges in the leeways of precedent. Not only are the areas wider but administrators are also less wellequipped with most of the steadying supports which judges enjoy: traditional techniques, settled bodies of doctrine, and the solace of esoteric legal fellowship. It is in the hight of this lack that we should perhaps understand current concern with nethods of determining "the public interest" in the administrator's context. Its drive is to secure the decision-maker's advertence to the full range and complexity of interests at stake, not merely those in adversary posture before him, but

$60 \mathrm{It}$ is obviously a disappointing outcome for the century of effort in England between the Donoughmore Committee of 1932 and the Franks Committee of 1957. On the Franks Report see Griffith, Tribunals and Inquiries, 22 MODERN L. REv. 125, 128, 143-45 (1959); Robson, Administrative Justice and Injustice: A Commentary on the Franks Report, 1958 Pub. L. 12; MacDermott, Protection from Power UNder Englisi LAw 81 (1957); PARKER, op. cit. supra note 42, at 57; WhyatT, JUSTICE REPORT.

61 Compare the trend of WHYATT, JUSTICE REPORT. For biterature on the related ombudsman question see Stone, Soctal Danensions of Law and Justice ch. $1, \S 24$ (forthcoming, 1965).

In the United States, Pound has observed that the Administrative Procedure Act, supra note 57 , was "a significant step toward a true administrative law," not merely describing what each particular administrative agency does but laying out "principles" of bow agencies are to proceed, applicable to agencies generally. He finds "ample room" for an "administrative law" based on the advancing experience and techniques of existing agencies. Pound, Foreword, 16 FED. B.J. 445, 450-51 (1956). Cf. the new Dutch draft law of appeals against administrative decisions, introduced at the Parliamentary Session 1961-62, No. 5363, of 13-7-1962. This provides for uniform normal process of appeal by public hearing before the Department of Contentious Matters of the Council of State, covering all official decisions except those of legislative organs, the Comptroller, polling officials, the Patent Council, and of course judicial and judicially controlled organs. Article 4 comprehensively brings the substantive fairness and merits of decisions, as well as matters of jurisdiction and procedure, under scrutiny. The grounds of appeal include claims that the decision contradicts a general rule, or is inspired by an objective other than that for which power was given. They also include complaints that the decision could not reasonably have been reached after a proper weighing of all interests concerned; and that it was contrary to generally acknowledged principles of "good administration." 
those more dispersed, and less articulate and organized ones to which we refer in terms like liberty, equality and opportunity. "The public interest" in this sense, it has been said, whether it be myth or not, "serves a hair-shirt function," persistently reminding us of the unorganized and underrepresented interests which decision will affect. Insistence on efficient procedures for marshalling such interests before the evaluating judgment ${ }^{62}$ has been characterized as "due process realism." This postulate, that decisions will be "in the public interest" in proportion as all the interests affected are first fully considered, would also be acceptable to many jurists as a statement about "justice." Similar juristic positions have indeed long held a dominant place. ${ }^{03}$ Whether or not such a position is a sufficient frame for final wisdom of judgment, it is indubitably an important prerequisite for all responsibility in judgment. It is also clear, lowever, that the further requisites go beyond any mere extensions of empirical bodies of knowledge from social science or otherwise, and beyond any techniques yet available for extending these.

Judge H. J. Friendly's recent work, The Federal Administrative Agencies (1962), is subtitled "The Need for Better Definition of Standards." Its thesis is that failure of the agencies to work out "better defintion" (perhaps the French word "précisation" better conveys his meaning) of the standards which they apply is an obstacle to achievement of equality and predictability, as well as to public criticism, adequate staff training, and confident investment in public utilities. It also encourages (he thinks) the "pressuring" of agencies. The thesis is admirably documented and salutary in itself. Yet it is also too widely stated, for it fails to take account of the variety of reasons why agencies are vested with particular kinds of quasi-legislative or quasi-judicial portions; not to speak of the variety of terms of legislative delegation, and of the degrees of susceptibility to use of definite standards which particular subject-matter will tolerate.

An able critic $^{64}$ has pointed out that when (as with the United States Civil Aviation Board) the legislator's directive refers to so vague a standard as "the public convemience and necessity," and so multiple a

62 Sorauf, The Public Interest Reconsidered, 19 J. Pourtics 616, 639 (1957). See ScruBERT, The PUBLIC INTEREST 203-07 (1954), for stimulating distinctions between what Schubert calls the "hair-shirt," "social engineering," and "due process realist" approaches. Juristically the "realist" label is unhelpful in view of the miscellaneous, unwanted baggage which it has long carried.

${ }^{63}$ See Stone, Human Law and Human Justice ch. 9, $\$ 4$ (forthcoming, 1965) comparing Schubert, The PUBLIC INTERest 205 (1954) and his citation of the present writer's position at 193.

84 Jaffe, Book Review, 76 HaRv. L. REv. 858, 862 (1963). 
one as "competition to the extent necessary to ensure the sound development of an air-transportation system properly adapted to the needs of ... foreign and domestic commerce . .. , of the Postal Service and of the national defence," we should not be optimistic about the chance of emergence of any standards viable from case to case. ${ }^{65}$ We should be even less optimistic when (as in that case) the functions delegated embrace both regulation of a going industry, and encouragement and control of its direction and rate of development at a most dynamic phase. Divergent philosophies and prognoses are here even more likely to leave their mark in vacillation of decision.

When we talk in general terms, therefore, about the need to work out and adhere to definite standards in administrative decision-making, we must be careful not to lose sight of at least two main dimensions of the problem. One is the number, vagueness and degree of potential conflicts among the policy indications which the legislator has directed to be accommodated. Another is the rate of change and movement in the facts relevant to each of these policies. These dimensions of a particular area of regulation also hold indications as to the functional aptitude of particular kinds of decision-making bodies. The more complex the pohicy-entanglement, especially in important and rapidly changing situations, the more should machinery approach ministerial or even cabinet decision. For decision lere slould be open to scrutiny and attack on the legislative level, so as to reduce, inter alia, the dangers of backroom pressures. At the other end of the scale, as policy adjustment becomes more tractable in more static situations, administrative tribunals and procedures may with functional aptness approach the judicial model, and the reasoned elaboration of policy adjustments may also approach that same model. In between is an endless range of variation in subjectmatter, mobility, kind and degree of organization of interests affected, which needs to be accommodated by variations in the nature and mode of representation of these interests on the tribunal and in its procedures and the arrangements for review.

Even as we approach the quasi-judicial end of the scales, moreover, we must be careful not to think of "the judicial model" in too abstract and idealized terms. For judicial tasks themselves also fall along a wide scale on which cases of precise issues of fact and applicable law in a clean-cut dispute between only two parties are only at one extreme end. At the other, as appellate counsel and judges well know, we have problems of lack of "defimite standards" not too different from those of

O5 Jaffe, Book Review, 65 YaIE L.J. 1068, 1073-76 discussing the Civil Aeronautics Act of 1938, 52 Stat. 973, 980 (1938) and the Federal Aviation Act of 1958, 72 Stat. 731 (1958), 49 U.S.C. $\S \S 1301-542$ (1958). See also Jaffe, supra note 64 at 860 . 
unpredictable case by case vacillations which Judge Friendly deplores among administrative agencies.

These insights allow us to see a certain link between demands that administrative action be more predictably grounded on "definite standards," and the campaign for a "return" of the United States Supreme Court to deciding cases according to "principles of law," and in particular "neutral principles of constitutional law," free of "result-orientation." The latter campaign proceeds in part on illusory notions of the nature of appellate decision-making. ${ }^{66}$ In other part it proceeds on a nostalgia for the law of a simpler, less mobile social phase, less plagued with endemic policy choices. Such elements, we fear, also contribute to present demands that admimistrative agencies should act more like their putative judicial models. Admittedly, even when the terms of such demands camot be fully met, the moral pressure which they bring upon decision-makers, and the efforts of decision-makers to conform, make for steadiness, sobriety and integrity of decision, up to a certain point. That limiting point is passed, however, when the pressure on decision-makers induces the paralyzing frustrations of attempting the impossible. And this is equally applicable to admimstrative and judicial decisionmakers.

\section{$\mathrm{V}$}

PROCEDURE AND ORGANIZATION AS CONTROLS OF ADMTNISTRATION ${ }^{07}$

We must now look briefly at the role of forms of procedure and

${ }^{66}$ See Stone, Legal System and Lawyers' Reasonings, chs. 6-8 (1964); Stone, Soctai Dincenstons of Law aNd JustTce, ch. 14, $\$$ 4-14 (forthcoming 1965); Stone, Result Orientation and Appellate Judgment, 37 RockY MT. L. REv. - (1964).

${ }^{67}$ An important move to secure a continuing overall review of the structures and procedures of the multitude of United States administrative agencies was initiated by the lato President Kennedy's establishment of the Administrative Conference of the United States in the hope of promoting a sense of unity and a degree of uniformity through interchange of ideas, techniques, and experience between agencies. Exec. Order No. 10934, 26 Fed. Reg. 3233 (1961). See Administrative Conference of the United States, Selected Reports, S. Doc. No. 24, 88th Cong., Ist Sess. (1963). See also Auerbach, The Federal Trade Commission, 48 MINv. L. REv. 383 (1964). This work grew out of Auerbach's work for the Conference on internal organization and procedure.

The Conference, whose chairman was Judge E. Prettyman of the United States Court of Appeals of the District of Columbia, consisted predominantly of menbers from nore than 30 agencies concerned in a major way with determining rights and obiggations of individuals by adjudication and rule-nuaking. See Selected Reports, supra 2-4. Apart fron important studies of particular concrete problems of particular agencies, the conference also promulgated, through its legal specialist staff directors, a series of studies of underlying problems, e.g., decisional autbority and and ex parte comnunications (Professor C. Auerbach), ratemaking (Professor Craunton), judicial review of N.L.R.B. and I.C.C. orders (Professors Kramer and Miller), hearing examiners and government lawyers (Professor Lester), discovery and subpoena (Professor Lester), governnient contracts (Professor Metzger). The work of the Conference before the suspension of its activitics (it is 
organization as means of control of administration. ${ }^{68}$ The legislature cannot supervise the massive and varied range of daily administrative tasks any more than it can itself perform these. Yet may it still not be able to lay down principles of administrative procedure and organization which will control these activities at a distance? May it not be, indeed, that the agencies may adopt such principles for themselves? In approaching such questions we must constantly remember that a prime purpose of delegation is to allow a flexible adaptation of organs and procedures to extended legal functions ${ }^{69}$ for which the older organs of government have fallen short. We must therefore be vigilant for the point at which by fixing the modus operandi we defeat the purpose of the operation itself, and reproduce in the newer agencies the very limitations, rigidities and maladaptations of the old which they are devised to make good.

Partly, no doubt, from sheer economy of effort, the agencies have themselves moved towards a degree of standardization in their orgamization and procedure. 70 Thus the "institutional" or "collegiate" techniques

hoped only temporarily) included basic reports in the area of personnel, internal organization and procedure, rule-making, licensing, compliance and enforcement, claims adjudication, and judicial review. Three volumes were also produced by the Office of Administrative Procedure in the Department of Justice at the request of the Conference Committee on Judicial Review describing the various kinds of administrative proceedings by federal agencies, with annotations to judicial review statutes, and analyzing these statutes by reference to 18 features of such provisions.

68 See Storon, Admonistrative Behavior (1947); Stmon, Smithburg \& Thompson, Public Admmistratron (1950); Waddo, The Admonistrative State (1948); Gulick, Notes on the Theory of Organization, in Papers oN THE ScIence of ADMINISTRation 3 (Gulick \& Urwick ed. 1937); Gladden, AN Introdoction To Public Administration (2d ed. 1952); Meyer, Adminnstrative Organization (1957); White, Public Admonistration (4th ed. 1955).

On particular United States problems, see ScEWARTz, AN INTrodUctron to AzTERICAN Admmistrative Law (1958), especially chs. 1, 3, 5-6; Administrative Procedure Act, supra note 57; Attorney General's Committee on Administrative Procedure, Report, S. Doc. No. 8, 77th Cong., 1st Sess. (1941); Comartssion on Organization of the Executtve Branch of the Governatent [Hoover Commisston], Legat Services aNd Procedure: A Report to Congress (1955); Commission on Organization of the Executive Branch of the Govermant [Hoover Commission], Task Force Report on Legat Services and Procedures (1955); Schwartz, The Model State Administrative Procedure Act, 33 Wasm. L. REv. 1 (1958).

On terminology, see MeYer, Admonistrattve Organtzation ch. 3 (1957), especially at 50 (vertical and horizontal perspectives), 50-52 (structures and function), 52-53 (organization), 55-56 (coordination), 56-57 (centralization and decentralization, and concentration and deconcentration).

68 See note 14 supra.

70 This is reflected in studies of the typology of the agencies. See also the discussion of the Morgan cases (Morgan v. United States, 304 U.S. 1 (1938); United States v. Morgan, 307 U.S. 183 (1939); United States v. Morgan, 313 U.S. 409 (1941)), in Davis, Institutional Administrative Decisions, 48 CoLUM. L. Rev. 172 (1948); see, on the question whether the 
of decision have become common among them, ${ }^{71}$ with resulting strengths and economies of group work weighed against weaknesses of anonymity, dispersed responsibility, and the tendency to divorce the investigatory from the deciding functions. Organs and procedure tested by experience for stable tasks obviously tend to be continued in order to assure reliable performance, to permit progress in performance to be tested, and to allow the steady pursuit of goals and encourage personnel incentives. ${ }^{72}$ Concurring with these tendencies within administration itself, rationalization, coordination and centralization of administrative processes have been sought by executive ${ }^{73}$ and legislative ${ }^{74}$ action.

A first underlying motif of such efforts is the aspiration which I designated a generation ago as basic to justice, namely, the minimum procedural requirement "that men's felt wants can be freely expressed; and that the law shall ... provide [that expression] with the channels through which it can compete effectively for ... the support of politically organized society."75 The explosive rise of administration is itself responsive to this aspiration. To keep faith with its origins, administration nust not only respect the legislative consensus, but be adequately receptive (when it nust make choices beyond this point) to the expression of the interests which it affects. This broad motif is sonetimes presented in split fashion as if the demand for participation of interests affected in policy-making (associated with regulation and delegated legislation), werè different from the deniand that interests affected by the implementing of policy (or quasi-adjudication) should have a hearing. ${ }^{78}$

deciding official must personally examine the records, id. at 188-92; his criticism of the Attorney General's Committee Report, id. at 192; and the effect of the Administrative Procedure Act, id. at 186-88.

71 See, e.g., Meyer, Amamristrative Organization (1957); Stmon, Administrative Benavror (1947); Davis, Institutional Administrative Decisions, 48 ColuMr. L. Rev. 173, 192-97 (1948); and Davis, English Administrative Law-An American View, 1962 PuD. L. 139.

72 Cf. Stmon, Adumnistrative BeHavior 110-22 (1947).

${ }^{73}$ The Hoover Commission found that the executive branch "is not organized into a workable number of major departments and agencies which the President can effectively direct." Comanission on Organization of the Executive Branch of the Government [Hoover Commission], Legal. Services and Procedure: A Report to Congress 4 (1955).

74 E.g., the United States Administrative Procedure Act, 60 Stat. 237 (1946), 5 U.S.C. $\$ \$ 1001-11$ (1958). On the individual states see Heady, Adminsstratrve Procedure LEgisistion IN the States (1952); Schwartz, The Model State Administrative Procedure Act, 33 WASE. L. REv. 1 (1958).

75 Stone, The Province and Function of the Law 785 (1950).

${ }^{78}$ See, e.g., Administrative Procedure Act, 60 Stat. 237 (1946), 5 U.S.C. $\$ \S 1001-11$ (1958), especially $\$ 2(c)$ (definition of "rule and rule-making" and definition of "order and adjudication") and \$§ 4-5 (establishing the dichotomy). And see ScHwARTz, op. cit. stipra note 68, at 106. On the similar distinction in the Model State Act see Schwartz, The Model State Administrative Procedure Act, 33 WASH. L. REv. 1 (1958). See also Fuchs, Procedire in Administrative Rule-Making, 52 HARV. L. REv. 259 (1938). 
Such a distinction holds dangers of encumbering administrative processes with separation of power concepts from which they were designed as an escape. It should at any rate not divert us from the real difficulties of expressing this first motif. One is the deep and wide conflict between the tasks of administration, which demand continuing flexibihty and adaptability for securing the interests legislatively accredited to it for protection. Another is the need to protect the particular interests exposed to administrative power in the course of performing these tasks. This is aggravated by the irony that, where policy discretions are wide, wise exercise usually demands flexibility. Yet it is precisely here that safeguards, towards which standardized and publicized procedures are the easiest means, seem most needed. Where, on the other hand, the ambit of discretion narrows, because of a clearly applicable rule, safeguards are less needed. Yet here it is also easier to have safeguards without impairing the administrator's performance of the task set.

The second motif underlying prescriptions of procedure and organization is the need for a minimum degree of coherence, accommodation and coordination as between the conglomerate, ubiquitous and evergrowing administrative agencies themselves. This concerns not only their relations inter se, but also their relations with older repositories of governmental power, especially the executive. Not only economy of money and effort but the very continuity of functioning of the enormous apparatus is here at stake. ${ }^{77}$ Here too we find an aggravating paradox. Coordination is most urgent where agencies most proliferate on new tasks. But these are also the areas where administrative achievement most needs trial and error, and therefore maneuvering space in procedure and organization. Both demands for coordination and those for flexibility speak in the name of the efficiency of political institutions.

While these two motifs engage attention towards neighboring horizons, the focus of each is on different centers of turbulence. The focus

\footnotetext{
- Compare I.C.C. Chairman Arpaia's rejection of any sharp distinction between policymaking and policy-implementation and therefore of the Hoover Commission proposals for transfer of I.C.C. quasi-judicial functions to the courts. He points out that these functions of the I.C.C. are merely tools, "use of which facilitates the exercise of its legislative or regulatory functions;" and that its hearings even when apparently between individuals are basically "akin to congressional hearings." Although, unlike Congress, it must act on evidence, "strict judicial treatment" would impede the Commission's work. Arpaia, The Independent Agency-A Necessary Instrument of Democratic Government, 69 HaRv. L. REv. 483, 497-98 (1956). Cf. text accompanying notes 7-21 supra, as to cases where the main purpose of delegation is to allow policy to emerge from particular determinations.

77 See generally Comanssion on Orgamzation of the EXEcutive Brance of the Governatent [Hoover Conouission], Report of the Conference on Admintstrative Procedure (1955); Krngdom, Irrprovement of Organization and Manageadent (1955).
} 
of the second motif is "Who should rule?" The focus of the first is "How shall we protect those subjected to the power of those who rule, whoever they are?"78 The former involves the question whether the legislative or the executive power should be arbiter of whatever coordination can be achieved. Here too, what seem to be mere problems of administrative organization and procedure merge into wider questions of the expansion of the range of legal intervention and the multifarious spreading of official powers and dilution of official responsibilities in our age of expanding legal orders. There is an ever-increasing diffusion of governniental powers and of responsibility for their exercise through a confusing multitude of points and levels, with all of which administration and its goals and performance become correspondingly entangled. While older institutions are also caught in this entanglement, their settled traditional patterns of organization and procedure protect them from niany of the traumas and tensions involved, and indeed tend to project these, when they do arise, into struggles surrounding the newer agencies.

Amid such complexities, again, we generalize at our peril. Yet some guiding statements can be made. First, it is clear that niany of the difficulties affecting both the motifs nientioned are endemic and recurrent, and concern the still formative relations of the administration to the fuller and settled framework of the modern legal order. Prima facie, therefore, questions concerning its procedure and orgamization require continual review at some point in governnent which is both high and central..$^{70}$

Second, it is clear that numerous useful organizational and procedural principles have already emerged,$^{80}$ and that many of them (e.g., United States Administrative Procedure $\mathrm{Act}^{81}$ ) are prescribed by the legislature ${ }^{82}$ as were the corresponding and mostly earlier British mensures. Such, for exanple, are the requirements for laying on the legisla-

78 Cf. Waldo, The Admtnstrative State 89 (1948).

$79 \mathrm{Cf}$. StMon, AdMTNistratTve BeEAvror 198-219 (1947) on "organizational identification" of officials in a department or agency below this level with the department's specific goals to the prejudice of balanced judgment vis-â-vis other departments or agencies.

80 For a stimulating and compact analysis and critique of these and other prescriptions see Schwartz, op. cit. supra note 68, at 55-75, 103-61. See also Administrative Procedure Act $\$ \S 4,5,60$ Stat. 237 (1946), 5 U.S.C. $\$ \S 1004-05$ (1958).

8160 Stat. 237 (1946), 5 U.S.C. $\$$ 1001-11 (1958).

82 The Act sought, for decisions affecting personal or property rights, to extend the best prevailing procedures to all agencies, and in some respects to improve on these. See, e.g., as to the role of the "hearing officer," ScHWarTz, op. cit. supra note 68, at 95, and Schwartz, The Model State Administrative Procedure Act, 33 WASH. L. REv. 1, 3 (1958). As to the required statements of findings and conclusions of fact and law under the Administrative Procedure Act \& 8(b), see ScHWARTz, op. cit. supra at 156-61. 
tive table, for conferences with parties affected, for antecedent publicity, for public hearings, for delays in coming into effect, for the hearing officer to join in deciding, and for the articulation of findings and the reasons or bases therefor. ${ }^{83}$

Third, these statements still leave open many questions: what business, what stage of stabilization, what organ, can wisely be subject to such general prescriptions? Where, for example, the object of the task conferred on the administrator is to allow policy to be worked out by confronting the exigencies of successive situations with expertise or experience drawn from similar cases, prematurely fixed routines may simply frustrate it. ${ }^{84}$ There are numerous intermediate levels also involving degrees of frustration. Clearly, so far as this is the case, no one should, or indeed does, expect that there can be any organizational and procedural regime comprehending all tasks of all agencies. Even prescriptions of defined ambit tailored by the legislature to particular agencies or functions or groups of them cannot go beyond a certain point. For, beyond that, the legislature is again balked by the same limits on its own capacity which led it to delegate the tasks in the first place. ${ }^{85}$ No doubt the potential ambit of such legislative prescriptions will increase as and where administrative tasks settle down and the organizational and procedural diversity are reduced by self-imposed patterns within the various agencies. They slould also find useful scope in removing many accidental differences, or those that have lost their functions, in the structure and procedure of many agencies. It would be sanguine to expect, lowever, that standardization will reach a level permitting general organizational and procedural conformity.

${ }^{83}$ See the prescription of the adversary procedure of the I.C.C. even in rule-making activity, on which the criticisms in ScrwarTz, op. cit. supra note 68, at 60-63 (1958), perhaps over-simplify the problem of separating what is "rule-making" from what is "adjudicatory." And see ScEwarTz, op. cit. supra at 158-61 (1958). See also the classical statement of the I.C.C. in American Glue Co. v. Boston \& Me. Ry., 191 I.C.C. 37 (1932) quoted in ScritarTz, op. cit. supra at 158-59. For a tribunal to guide the public as to its likely holdings, an attempt must be made to come to similar decisions on similar facts and to give the reasons without which assessments of "similarity" is impossible. See Attorney General's Committee on Administrative Procedure, Report, S. Doc. No. 8, 77th Cong., 1st Sess. 30 (1941) and other materials collected in ScHWARTz, op. cit. supra at 156-61 (1958).

84 See the strictures on the Hoover Commission and its Task Force in Arpaia, The Independent Agency-A Necessary Instrument of Democratic Government, 69 HARv. L. REv. 483, 492-94 (1956), which accuses them of assuming "that a procedure suitable for one agency is suitable for another agency performing essentially different functions;" and of failing "to distinguish the nature, purpose, and functions of each agency and to identify precisely the evils, if any, requiring correction." See also Jaffe, English Administrative Law-A Reply to Professor Davis, 1962 PuB. L. 407, 413 (on the "umiform judicial mould"); ScrwarTz, op. cit. supra note 68, at 63-68 (1958).

85 See note 83 supra. 
We repeatedly face in this area the truth that making omelettes requires the breaking of eggs. We cannot set the law to new tasks intractable to old methods, without using new methods and to that extent ousting old ones. No doubt we must count the eggs we break, and break them only for making omelettes. Yet however careful we are, the steadying effect of organizational and procedural checks on administrative discretion cannot amount to a full guarantee of either wisclom or justice. They are bound, incleed, to fall far short of the level to which we are accustomed for choices within appellate judicial leeways. ${ }^{86}$ This proceeds from the practicalities of justice as well as from those of admimistration. When the administrator's justice for particular claimants seems to fall short, this may sometimes be by collision with the evaluations of justice for menibers of the community generally enıbodied in the very legislative consensus which conferred the administrator's task. At any point when his tasks cannot be performed without pruning the guarantees of justice in particular cases, we have a conflict within justice itself, as it is given to him to administer. We must try to distinguish this from a conflict between justice and mere bureaucratic arbitrariness of ineptitude.

That we may here face conflicts within the requirements of justice itself reflects back on the nodern legislator's own heavy responsibilities. He must not venture lightly into areas where an attempt to extend general benefits in title of justice entails too wide-ranging an arbitrariness in administration of individual cases. He must, when he does venture, attend more closely than he has often done to the specific desiguation of tasks or of the interests specially committed to the concern of the administrator. ${ }^{87}$ This also reflects forward to the problems of education of administrators for these responsibilities, and for the urgent need of more systematic and sophisticated concern of this education with the inescapable problems of justice-evaluation. This need for overt concern of administrators with the deeper problems of justice is a great matter in itself, and we can here venture only one or two concluding observations concerning it.

On the one hand, we cannot simply stop at the black and white truth that a decision will tend to be more just when the decision-maker is always fully aware of the choices available for his creative exercise,

86 Cf. Arpaia, The Independent Agency-A Necessary Instrument of Democratic Government, 69 HARV. L. REv. 483, 505 (1956).

87 Cf. Easton, The Polmucal System 213-18 (1953); Staron, Admonistrative BeHAVIOR (1947); MEYER, ADMTINISTRATIVE ORGANIZATION 68-69 (1957). 
and of the motivations which determine his judgment. We must think not of a single decision but of endless ongoing series of decisions; not of one man deciding one case, but of decision-making institutions in their generations. We must be aware that with administrators, as with appellate judges, we face not black and white but uncomfortably grey questions precisely because of the effect on the viability and efficiency of decision-making institutions, of insisting that decision-makers should always make their choices in full self-awareness. ${ }^{88}$ No doubt most administrators already have greater awareness than most judges of the choices open to them, so that the stresses from fuller self-awareness would tend to be less. Yet they also face a vastly greater flood of manysided and multi-dimensioned policy problems to which they must marshall great masses of data. To ask administrators also to struggle directly and constantly with our notions of justice, which are so precious an inheritance from Judaeo-Christian and Greek traditions, as these have been nurtured in our several communities, may seem like the last straw. Yet they cannot be wholly dispensed from this. When administrators act as if they are so dispensed they must come to need forgiveness; for without some agonizing on these nratters, administrators know not what they do.

The very notion of "administration" itself, on the other hand, if we think clearly, has a built-in presupposition of some aim or plan or policy to whose achievement the activity is instrumental. Insofar as the legislator provides a sufficiently precise aim or plan or policy, this can be the administrator's measure. Yet it seenis now to be common ground that absence or imprecision of the legislator's objectives is a chronic problem for the nodern administrator. It also seenis unlikely that we can expect to improve this position. It, thus, becomes correspondingly important that administrators, and others concerned with these functions as lawyers or scholars, should address themselves more directly to the study and criticism of the elements and niethods of evaluation in the social fields. ${ }^{89}$ What is thus iniphed for the various roles, for instance concerning recruitment and training, and the balance between practical and theoretical skills and insights, is complex and debatable. ${ }^{.0}$

88 Stone, Soctar DRrensions of Law and JUStice ch. 14, § 13 (forthcoming, 1965).

89 This, of course, is no light requirement. For a modern view of the range of action involved see Stone, HuMan Law and Human Jostice (forthcoming, 1965), especially chs. $1,2,10,11$.

90 See the discussion in Waido, The Adnonistrative State, 22-46, 192-205 (1948) and literature cited therein at 31; MEYER, ADMInistrattve OrgantzatTon 17-22 (1957). The latter offers a valuable but necessarily over-simplified outbine of the development of the "philosoply" of administrative tasks. 
The need, nevertheless, among all of them for a revived concern and capacity for historical and philosophical clarification and criticism of ideals currently striven for, seems beyond debate. Equally imperative is the ability and willingness to bring these ideals to articulation without, on the one hand, an embarrassed sense that they are naive and unworthy preoccupations for "scientific" or "practical" men, or, on the other hand, claiming that they have the sanctity of the ultimate. Quite the contrary, it is above all in the clarification and criticism of the ideals we currently strive to realize, and not in materialism based on cynicism or despair, that we must seek correctives for our disappointed hopes that the empirically won data of social science would somehow suffice to guide social action. Today more than ever, and for the administrator as for other social actors, problems of evaluation, and above all those of justice, stand ever, like avenging angels, in the path of social and political action. 